\title{
SCALE-UP STUDIES ON IMMOBILIZATION OF LACTOPEROXIDASE USING MILK WHEY FOR PRODUCING ANTIMICROBIAL AGENT
}

\author{
A. N. Al-Baarri ${ }^{1, *}$, M. Ogawa ${ }^{1}$ and S. Hayakawa ${ }^{1}$ \\ ${ }^{1}$ Department of Applied Biological Sciences, Kagawa University, 2393, Ikenobe, \\ Mikicho, Kitagun, Kagawa 761-0795, Japan \\ "Permanent address: Faculty of Animal Agriculture, Diponegoro University, \\ Tembalang Campus, Semarang 50275 - Indonesia \\ Corresponding Email: albari@undip.ac.id
}

Received July 14, 2010; Accepted August 26, 2010

\begin{abstract}
Hypothiocyanite $\left(\mathrm{OSCN}^{-}\right)$, produced by lactoperoxidase (LPO) in the presence of $\mathrm{SCN}^{-}$and $\mathrm{H}_{2} \mathrm{O}_{2}$, inhibits the growth of bacteria. This inhibition is called by LPO system (LPOS). Our laboratory scale study in previous experiment showed that whey immobilized on SP-Sepharose Fast Flow (SP-FF) could produce $\mathrm{OSCN}^{-}$continuously. Then, the purpose of this study is to scale up continuous production of $\mathrm{OSCN}^{-}$using immobilized whey. Immobilized whey was generated by circulating various amounts of whey through SP-FF. To generate $\mathrm{OSCN}^{-}, 10 \mathrm{ml}$ of the substrate solution containing $0.5 \mathrm{mM} \mathrm{SCN}^{-}$and $0.5 \mathrm{mM} \mathrm{H}_{2} \mathrm{O}_{2}$, was circulated through immobilized whey and followed by washing with pure water. The next cycle was done by circulating a fresh $10 \mathrm{ml}$ of substrate solution at the same concentration. The result indicated that a stable immobilization efficiency of more than $90 \%$ was achieved in the SP-FF circulated with $300 \mathrm{ml}$ or less of whey per gram of SP-FF. When stored at $4^{\circ} \mathrm{C}$, immobilized whey retained $80 \%$ LPO activity until 3 weeks storage. The reaction solution discharged from immobilized whey was observed to contain approximately $0.4 \mathrm{mM} \mathrm{OSCN}^{-}$. The experiment using $1.0 \mathrm{~g}$ of immobilized whey produced a stable $0.4 \mathrm{mM} \mathrm{OSCN}^{-}$production and antimicrobial activity for at least 6 cycles. The increase in resin volume accompanied by the increase in whey volume resulted the extension of a stable $\mathrm{OSCN}^{-}$production. The experiment using recycled SP-FF did not affect to the stability of $\mathrm{OSCN}^{-}$production and antimicrobial activity. These results may open the way for the large-scale production of $\mathrm{OSCN}^{-}$.

Keyword: immobilized whey, sepharose, lactoperoxidase system, antimicrobial agent, Salmonella enteritidis.

\section{INTRODUCTION}

The lactoperoxidase system (LPOS) consists of three components: the lactoperoxidase (LPO), thiocyanate $\left(\mathrm{SCN}^{-}\right)$and hydrogen peroxide $\left(\mathrm{H}_{2} \mathrm{O}_{2}\right)$. LPO is an oxidoreductase and catalyses the oxidation of $\mathrm{SCN}^{-}$at the expense of $\mathrm{H}_{2} \mathrm{O}_{2}$, to generate the antimicrobial product of hypothiocyanite ion $\left(\mathrm{OSCN}^{-}\right)$. This reaction product has a broad spectrum of antimicrobial effect (Min et al., 2005; Reiter, 1985; Saad, 2008; Seifu et al., 2005; Seifu et al., 2004; Wolfson and Sumner, 1993). The product inhibits microorganisms by the oxidation of sulphydryl groups of microbial enzymes (Gurtler and Beuchat, 2007; Kussendrager and Hooijdonk, 2000; Wit and Hooydonk, 1996). International Dairy Federation recommends the use of LPOS to preserve raw milk during transport in developing

countries (FAO, 2005; FSANZ, 2002; Gurtler and Beuchat, 2007). Furthermore, LPOS has been studied as a means to control pathogens and spoilage microorganisms in pasteurized milk (Marks et al., 2001; Seifu et al., 2004), caprine milk (Seifu et al., 2004), infant formula (Banks and Board, 1985; Gurtler and Beuchat, 2007), fruit and vegetable juices (Nguyen et al., 2005; Raybaudi-Massilia et al., 2009), beef (Elliot et al., 2004) and poultry (Borch et al., 1989; Touch et al., 2004).

Purification of LPO from bovine milk is costly for practical use in food industry (Touch $e t$ al., 2004; Al-Baarri et al., 2010c). Our previous experiment immobilized bovine whey, which is rich of LPO content, into SP-Sepharose Fast Flow (SP-FF) for repeating $\mathrm{OSCN}^{-}$production (AlBaarri et al., 2010a). The use of whey might reduce the cost because it can skip the purification
\end{abstract}


process of LPO (Al-Baarri et al., 2010b). Whey, which is a byproduct of cheese production, is a source of LPO and it is cheap in price. Thus, the utilization of whey seems to meet the requirement for large-scale production of $\mathrm{OSCN}^{-}$. In other hand, SP-FF is known as a support for immobilization that easy to scale-up and able to reuse. Therefore, we engaged the experiment to scale-up the immobilized whey and reuse the SPFF.

The objective of this study is to establish the large-scale production of $\mathrm{OSCN}^{-}$by scalling up the volume of resin and whey, and to determine effect of recycling of SP-FF on $\mathrm{OSCN}^{-}$ production and antimicrobial activity againts Salmonella enteritidis.

\section{MATERIALS AND METHODS}

\section{Materials}

Fresh cow's milk was provided by a local dairy farm. Rennet was purchased from Hansens Kaselab Pulver, Copenhagen, Denmark. Lactic acid, $\mathrm{H}_{2} \mathrm{O}_{2}, \quad \mathrm{KSCN}$, and 2,2'-azino-bis(3ethylbenzthiazoline-6-sulphonic acid) or ABTS were purchased from Wako Pure Chemical Industries, Tokyo, Japan. SP-FF was purchased from Amersham Pharmacia Biotech, Sweden. S. enteritidis NBRC 3313 was obtained from the Institute for Fermentation, Osaka, Japan. Unless otherwise specified, all other chemicals were reagent grade.

\section{Preparation of whey}

Two liter fresh cow's milk was centrifuged at $10,300 \times \mathrm{g}$ at $10^{\circ} \mathrm{C}$ for $30 \mathrm{~min}$ to minimize the fat. The skim milk was treated with $0.02 \%(\mathrm{w} / \mathrm{v})$ rennet and $2.0 \mathrm{ml}$ lactic acid/liter milk at $30^{\circ} \mathrm{C}$ for $30 \mathrm{~min}$. The precipitated caseins were removed by filtration through a sterilized filter cloth and then through filter paper under vacuum condition. The resultant filtrate was used as whey.

\section{The procedure of immobilization of whey}

SP-FF was used as a carrier for immobilization of whey. Whey at the volume of $50-500 \mathrm{ml}$ (LPO activity, approximately 2.5 $\mathrm{U} / \mathrm{ml})$ was added to a glass column $(0.5 \times 10 \mathrm{~cm})$ packed with 1.0 and $10.0 \mathrm{~g}$ of SP-FF, which were washed with $1.0 \mathrm{ml}$ and $10.0 \mathrm{ml}$ of $10 \mathrm{mM}$ PB ( $\mathrm{pH}$ 7.0) beforehand, respectively. The whey solution was circulated through the column using a feedback tubing and a peristaltic pump. The circulation was done at the flow rate of 1.0 $\mathrm{ml} / \mathrm{min}$. After draining the whey away, the resin was washed three times with 3.0 and $30.0 \mathrm{ml}$ of $10 \mathrm{mM}$ PB (pH 7.0) for 1.0 and $10.0 \mathrm{~g}$ of SP-FF, respectively, to remove unbound proteins. The immobilization efficiency (IE) was calculated as follows: $\operatorname{IE}(\%)=\tilde{\mathrm{E}_{1}} \mathrm{E}_{0} \times 100$, where $\mathrm{E}_{0}$ is the total LPO activity added to the resin $(\mathrm{U})$ and $\mathrm{E}_{1}$ is the total LPO activity embedded in the resin (U).

\section{Determination of LPO activity of immobilized whey}

One hundred milligrams of immobilized whey was placed in a $0.5 \times 10 \mathrm{~cm}$ glass column. The column was connected to a tubing. A peristaltic pump was used for the efflux of solutions from the column. Four hundred and fifty microliter of $1.0 \mathrm{mM}$ ABTS in $10 \mathrm{mM}$ acetate buffer (pH 4.4) and $450 \mu 1$ of $0.55 \mathrm{mM} \mathrm{H}_{2} \mathrm{O}_{2}$ in pure water were gently poured into the glass column. After enzymatic reaction for $20 \mathrm{~s}$, the reaction solution was drained by suction at maximum power using the peristaltic pump. Immediately, the absorbance of the reaction solution was monitored at $412 \mathrm{~nm}$. One unit of LPO enzymatic activity was expressed as the amount of enzyme needed to oxidize $1 \mu \mathrm{mol}$ ABTS/min. The molar extinction coefficient of ABTS at $412 \mathrm{~nm}$ was $32,400 \mathrm{M}^{-1} \mathrm{~cm}^{-1}$.

\section{Production of $\mathrm{OSCN}^{-}$using immobilized whey}

The amount of 1.0 and 10.0 gram of immobilized whey was placed in a glass column connected to a feedback tubing with a peristaltic pump. Five milliliter of $1.0 \mathrm{mM} \mathrm{KSCN}$ and the same volume of $1.0 \mathrm{mM} \mathrm{H}_{2} \mathrm{O}_{2}$ were added to the column and subsequently circulated through the column using the peristaltic pump. The flow rate of circulation was kept at $1.0 \mathrm{ml}$ per minute. Following the circulation, the reaction solution was collected into a glass tube. After reaction solution was completely discharged, the column was washed by circulating 5.0 and $50.0 \mathrm{ml}$ of pure water for 1.0 and $10.0 \mathrm{~g}$ of SP-FF, respectively. Just after the washing, the LPO enzymatic activity of the immobilized resin was measured using the above-mentioned procedure. A series of processes including the circulation of reaction solution containing substrate and washing was repeated 10 times. The reaction solution discharged from immobilized whey was observed for $\left[\mathrm{OSCN}^{-}\right]$, $\left[\mathrm{SCN}^{-}\right],\left[\mathrm{H}_{2} \mathrm{O}_{2}\right]$, and antimicrobial activity.

\section{Determination of [ $\left.\mathrm{OSCN}^{-}\right]$ \\ $\mathrm{OSCN}^{-}$concentration was determined}


according to the method of Aune and Thomas (1977) with minor modifications. The principle of the method was based on the oxidation of 5-thio2-nitrobenzoic acid (Nbs) to 5,5'-dithiobis-2nitrobenzoic acid $\left(\mathrm{Nbs}_{2}\right)$. $\mathrm{Nbs}$ stock solution was prepared by adding $2.0 \mu \mathrm{l}$ of mercaptoethanol to $10.0 \mathrm{ml}$ of $\mathrm{Nbs}$ solution diluted to $0.5 \mathrm{mM}$ with $0.1 \mathrm{M} \quad \mathrm{PB} \quad(\mathrm{pH}$ 7.2) containing $5.0 \mathrm{mM}$ ethylenediaminetetraacetic acid (EDTA). The Nbs stock solution was prepared fresh daily and kept on ice. Before OSCN ${ }^{-}$determination, $\mathrm{H}_{2} \mathrm{O}_{2}$ present in a sample was removed by adding $20 \mu \mathrm{l}$ of 1.0 $\mathrm{mg} / \mathrm{ml}$ catalase solution to $1.0 \mathrm{ml}$ sample. Four milliliter of $0.1 \mathrm{M} \mathrm{PB}(\mathrm{pH} 7.2$ ) containing $5.0 \mathrm{mM}$ EDTA was added to $0.1 \mathrm{ml}$ of the $\mathrm{H}_{2} \mathrm{O}_{2}$-free sample solution, followed by the addition of 0.5 $\mathrm{ml}$ of $\mathrm{Nbs}$ stock solution. Immediately, the absorbance of the mixture was measured at 412 $\mathrm{nm}$. The concentration of remaining $\mathrm{Nbs}$ was calculated from the absorbance reading, with assumption of a molar absorption coefficient of $13,600 \mathrm{M}^{-1} \mathrm{~cm}^{-1}$ for Nbs.

\section{Determination of $\left[\mathrm{SCN}^{-}\right]$}

The measurement of $\left[\mathrm{SCN}^{-}\right]$was performed according to the method of Pruitt et al. (1990) with minor modifications. Ten gram of $\mathrm{Fe}\left(\mathrm{NO}_{3}\right)_{3} \bullet 9 \mathrm{H}_{2} \mathrm{O}$ was dissolved in $20.0 \mathrm{ml}$ of concentrated nitric acid. Water was added to the solution to give the final volume of $200 \mathrm{ml}$. An aliquot of sample was added to nine volumes of the ferric nitrate solution. The absorbance of mixture was measured at $460 \mathrm{~nm}$. The $\left[\mathrm{SCN}^{-}\right]$ concentration of sample was calculated from an established standard curve of KSCN solutions of known concentrations.

\section{Determination of $\left[\mathrm{H}_{2} \mathrm{O}_{2}\right]$}

$\mathrm{H}_{2} \mathrm{O}_{2}$ concentration was determined using ABTS and horseradish peroxidase (HRP). A 450$\mu 1$ of sample was mixed with $450 \mu \mathrm{l}$ of $1.23 \mathrm{mM}$ ABTS in $10 \mathrm{mM} \mathrm{PB} \mathrm{(pH} \mathrm{7.0).} \mathrm{A} \mathrm{hundred}$ microliter of $6.67 \mu \mathrm{g} / \mathrm{ml} \mathrm{HRP} \mathrm{in} 10 \mathrm{mM} \mathrm{PB}(\mathrm{pH}$ 7.0) was added to the solution mixture. Immediately after the enzyme addition, the absorbance of the mixture containing the enzyme was monitored at $412 \mathrm{~nm}$ for $20 \mathrm{~s}$. The absorbance change at $412 \mathrm{~nm}\left(\Delta \mathrm{A}_{412}\right)$ was used to estimate $\mathrm{H}_{2} \mathrm{O}_{2}$ concentration, based on previouslyestablished standard curve of $\Delta \mathrm{A}_{412}$ and $\mathrm{H}_{2} \mathrm{O}_{2}$ concentration.

\section{Antimicrobial activity assay}

S. enteritidis were cultured at $37^{\circ} \mathrm{C}$ overnight in sterile agar slants containing $1.0 \%$ polypeptone, $0.5 \%$ yeast extract, $0.3 \% \mathrm{D}$-glucose, $1.0 \% \mathrm{NaCl}, 0.1 \% \mathrm{MgSO}_{4} \cdot 7 \mathrm{H}_{2} \mathrm{O}$, and $1.5 \%$ agar at $\mathrm{pH}$ 7.0. The bacteria in the slants were suspended in sterile $0.88 \% \mathrm{NaCl}$ solution. The density of bacteria was estimated from the absorbance at 600 $\mathrm{nm}$ using previously-established standard curve of S. enteritidis (CFU/ml) and absorbance.

Sample solution was filtered through a 0.22 $\mu \mathrm{m}$ filter unit. A 360- $\mu$ l aliquot of sample was mixed with $40 \mu \mathrm{l}$ of $S$. enteritidis (ca. $7 \mathrm{log}$ $\mathrm{CFU} / \mathrm{ml}$ ) and the mixture was incubated at $30^{\circ} \mathrm{C}$ for $3 \mathrm{~h}$. Subsequently, serial dilutions of the mixture were prepared with sterile $0.88 \% \mathrm{NaCl}$ solution. Diluted mixture $(100 \mu \mathrm{l})$ was spread onto desoxycholate-hydrogen sulfide lactose agar plates. The plates were incubated at $37^{\circ} \mathrm{C}$ for 24 $\mathrm{h}$. The colony number on each plate was counted. Antimicrobial activity of sample was expressed by $\log N_{0} / N_{\mathrm{t}}$, where $N_{0}$ is CFU per milliliter of the substrate solution $\left(\mathrm{SCN}^{-}\right.$and $\left.\mathrm{H}_{2} \mathrm{O}_{2}\right)$ before passing the resin and $N_{\mathrm{t}}$ is CFU per milliliter of the sample after passing the resin.

\section{RESULTS AND DISCUSSION}

\section{Immobilization efficiency}

Enzyme immobilization onto a support matrix is achieved in three different modes: adsorption, cross-linkage and entrapment (Tatsumi et al., 1996; Wisdom et al., 1984). Among those, the adsorption is the simplest because the adsorption can be achieved by circulating the enzyme through resin (Dwevedi and Kayastha, 2009). According to the manufacturer, the SP-FF resin can be recycled by washing out of the deteriorated LPO and followed by attaching fresh LPO again onto resin. This simple method seems to meet the industrial requirement.

The adsorptive capacity may differ among type of resin (Orlando et al., 2002). To clarify the maximum adsorptive capacity of SP-FF towards whey adsorption, whey in the volume range of 100-500 ml was circulated through $1.0 \mathrm{~g}$ of SPFF. The immobilization efficiency (IE) was calculated base on LPO activity embedded in the resin and LPO activity employed. The result is presented in Fig. 1. It can be seen that IE reached the value of more than $90 \%$ and did not reveal notable change in the loading of 100-300 ml whey. This result suggests that most the LPO in the whey were adsorbed onto the resin. The whey loading of over $300 \mathrm{ml}$ resulted in the decrease of 


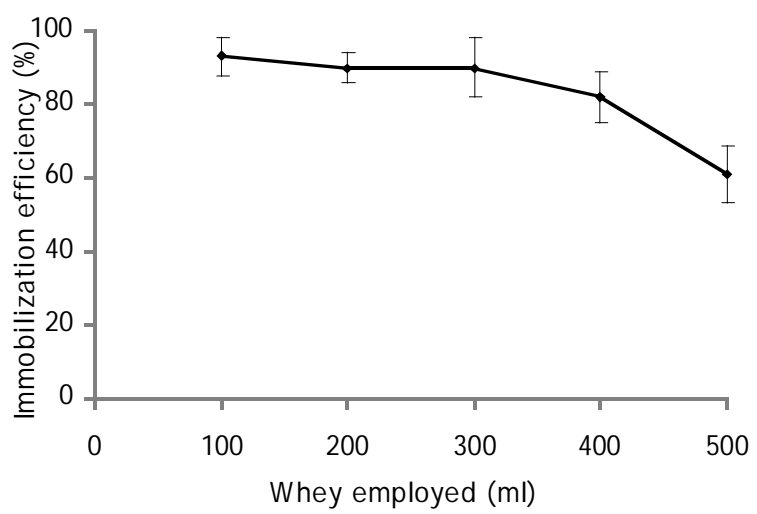

Figure 1. Effect of the increase in whey volume added into SP-FF column on immobilization efficiency. The $100-500 \mathrm{ml}$ of whey was immobilized into $1.0 \mathrm{~g}$ of SP-FF. Data point are mean of values based on triplicate experiment. Error bars represent standard deviation of the mean.

IE. When $500 \mathrm{ml}$ of whey was used, IE decreased to $61 \%$, suggesting that the appreciable amount of LPO was not captured by the resin. Thus, $1.0 \mathrm{~g}$ of SP-FF has capacity to effectively adsorb $300 \mathrm{ml}$ of whey. The observation of LPO activity in whey resulted in the value of $c a .2 .5 \mathrm{U} / \mathrm{ml}$. Based on this calculation, $300 \mathrm{ml}$ of whey equal to 750 $\mathrm{U} / \mathrm{ml}$ of LPO activity; thus, it can be concluded that an optimum adsorptive capacity of resin is ca. $750 \mathrm{U} / \mathrm{ml}$ LPO per gram resin. This result is comparable to our previous finding using pure LPO, which resulted the optimum IE of approximately $600 \mathrm{U} / \mathrm{ml}$ per gram resin (AlBaarri et al., 2010).

\section{Stability of immobilized whey}

The stability of immobilized whey stored at $4^{\circ} \mathrm{C}$ for 4 weeks is shown in Fig. 2. Immobilized whey remained a stable LPO activity for up to 4 weeks, as seen from LPO activity of about $80 \%$. By contrast, the enzymatic activity of whey was markedly reduced with an increase of storage time. Whey stored within three and four weeks resulted in 88 and $97 \%$ loss of its LPO activity, respectively. This result indicates that the immobilization stabilizes the enzyme activity during storage.

The loss of the LPO activity in immobilized whey during storage could be attributed to the release of the enzyme from resin due to the partial degradation of the resin network (Ichi et al., 2009;

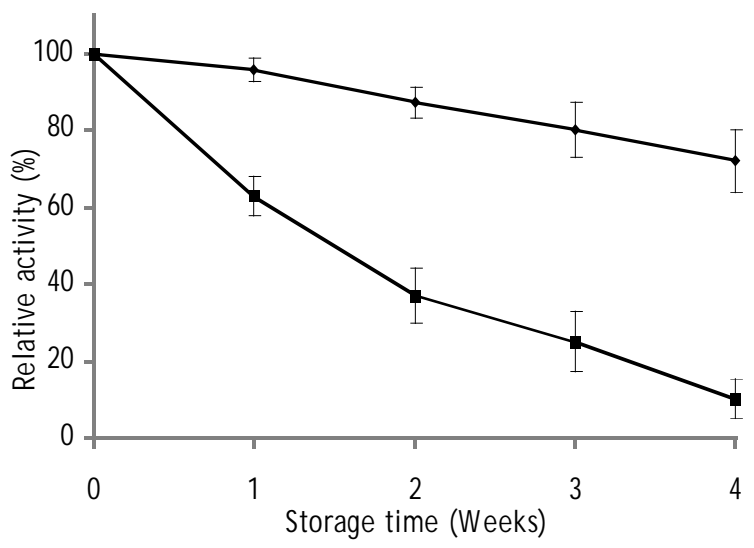

Figure 2. The storage stability of immobilized whey stored in $10 \mathrm{mM} \mathrm{PB}(\mathrm{pH} 7.0)$ at $4^{\circ} \mathrm{C}$ for 4 weeks. The immobilized whey was achieved by circulating $100 \mathrm{ml}$ of whey to $1.0 \mathrm{~g}$ of SP-FF and followed by washing to remove unbound LPO. $100 \%$ of relative activity means the initial activity of immobilized whey right after immobilization process. The symbols represent immobilized whey $(\bullet)$ and free enzyme (ם). Data points are mean values based on triplicate determination. Error bars represent standard deviation of the mean.

Noda et al., 2001; Zhou and Lim, 2009). Besides, the storage could also denatures the LPO activity (Kussendrager and Hooijdonk, 2000; Seifu et al., 2005).

\section{Continuous production of $\mathrm{OSCN}^{-}$}

Whey immobilized on SP-FF was applied to continuously produce $\mathrm{OSCN}^{-}$by circulating the resin with the substrates $\mathrm{SCN}^{-}$and $\mathrm{H}_{2} \mathrm{O}_{2}$ for many times. The result of substrate and product quantitative of enzymatic reaction using immobilized whey is presented in Fig 3. All the $\mathrm{SCN}^{-}$and $\mathrm{H}_{2} \mathrm{O}_{2}$ in the reaction solution were consumed at the first of 7 cycles of LPOS reaction (Fig $3 \mathrm{a}$ and Fig $3 \mathrm{~b}$ ). At the $10^{\text {th }}$ cycle, $0.2 \mathrm{mM}$ or more $\left[\mathrm{SCN}^{-}\right]$and $\left[\mathrm{H}_{2} \mathrm{O}_{2}\right]$ was found in the reaction solution indicating the decrease in substrate consumption by LPO in immobilized whey. The $\left[\mathrm{SCN}^{-}\right]$and $\left[\mathrm{H}_{2} \mathrm{O}_{2}\right]$ in reaction solution might relate to the volume of employed whey for immobilization. The higher volume of whey, the less of $\left[\mathrm{SCN}^{-}\right]$and $\left[\mathrm{H}_{2} \mathrm{O}_{2}\right]$ was found in the reaction solution discharged from immobilized whey. This may be due to high LPO activity in immobilized whey.

The decrease in substrate consumption may be explained by the decrease of LPO enzymatic activity along the increase in the number of LPOS reaction cycle (Al-Baarri et al., 2010). The loss of 

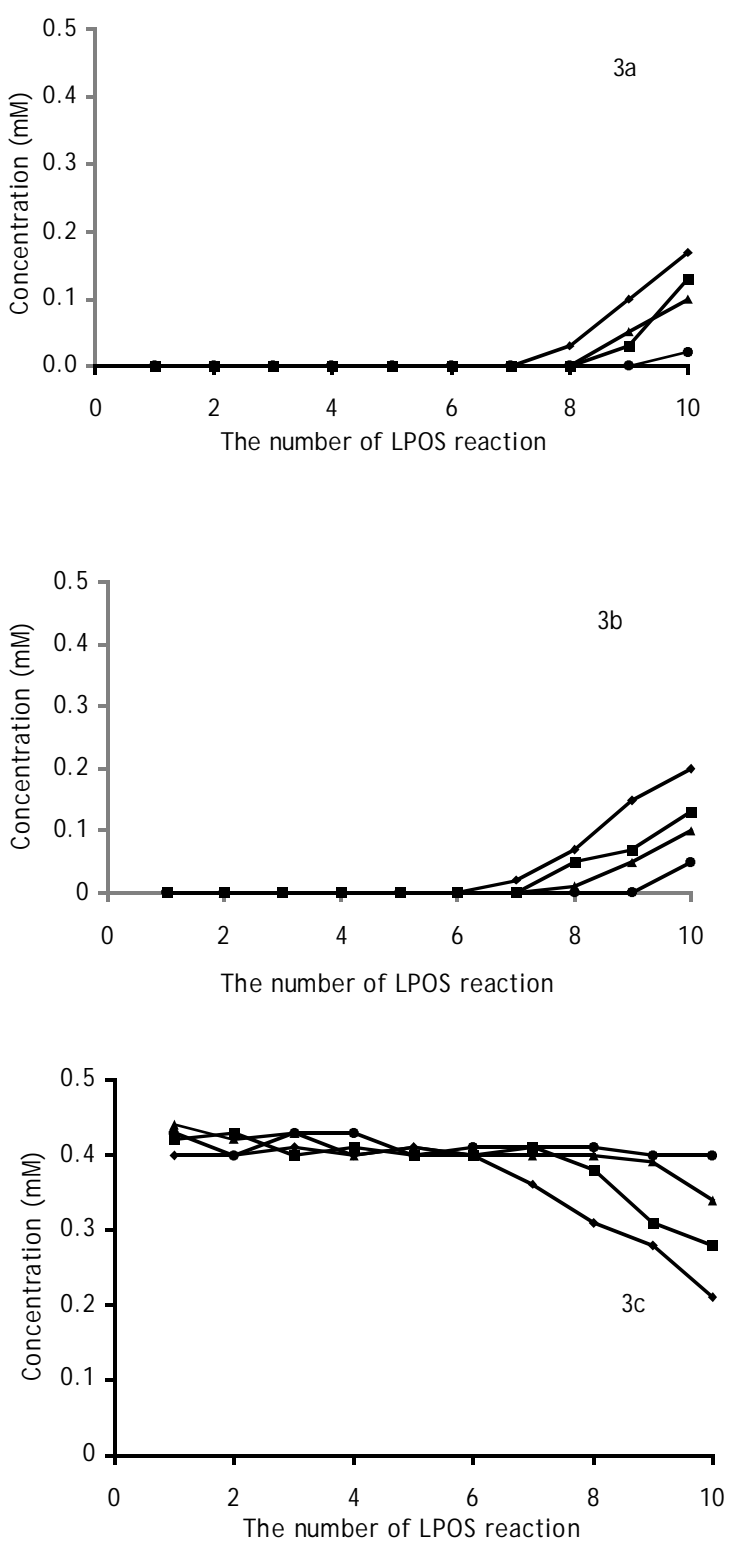

Figure 3. Concentration of $\mathrm{SCN}^{-}, \mathrm{H}_{2} \mathrm{O}_{2}$, and

$\mathrm{OSCN}^{-}$in the reaction solutions discharged from immobilized whey. Immobilized whey was achieved by circulating $50(\bullet), 100(\boldsymbol{\bullet}), 150(\mathbf{\Delta})$, $200(\bullet) \mathrm{ml}$ of whey through $1.0 \mathrm{~g}$ of SP-FF.

Concentrations of $\operatorname{SCN}^{-}(\mathrm{a}), \mathrm{H}_{2} \mathrm{O}_{2}(\mathrm{~b})$, and

$\mathrm{OSCN}^{-}$(c) were detected using procedure mentioned in materials and method section. pointare mean values triplicate determination.

enzymatic activity may be brought about by the substrates of LPO. It is well documented that $\mathrm{H}_{2} \mathrm{O}_{2}$ itself reduce LPO enzymatic activity (Kussendrager and Hooijdonk, 2000; Seifu et al., 2005). $\mathrm{SCN}^{-}$was also reported to restrain enzymatic action by binding to LPO's heme cavity (Sheikh et al., 2009; Singh et al., 2009; Singh et al., 2008).

The concentration of $\mathrm{OSCN}^{-}$produced using immobilized whey is showed in Fig. 3c. The $\mathrm{OSCN}^{-}$concentration of approximately $0.4 \mathrm{mM}$ was achieved in the first 6 cycles of LPOS reaction and followed by the decrease in the concentration. The $\mathrm{OSCN}^{-}$concentration observed at tenth cycle of reaction solution was detected to contain $\mathrm{OSCN}^{-}$concentration of 0.21 , $0.28,0.34 \mathrm{mM}$ when $50,100,150 \mathrm{ml}$ of whey was used, respectively. When $200 \mathrm{ml}$ of whey was used, a stable $\mathrm{OSCN}^{-}$production was observed for ten reaction cycles. These results suggest that the increase of whey volume extended the stable production of $\mathrm{OSCN}^{-}$.

\section{Antimicrobial activity of reaction solution}

Figure 4a shows the antimicrobial activity of reaction solution obtained from the circulation of substrate solution through $1.0 \mathrm{~g}$ of immobilized whey, against $S$. enteritidis. Immobilized enzyme obtained from loading of $50-150 \mathrm{ml}$ of whey, generated a stable antimicrobial production (approximately $5 \log N_{0} / N_{\mathrm{t}}$ ) for 8 cycles or less while loading with $200 \mathrm{ml}$ of whey, produced a stable antimicrobial activity for 10 cycles of LPOS reaction. Further experiment of the latter treatment showed a stable antimicrobial activity for 17 cycles of LPOS reaction (data not presented). The antimicrobial activity produced using higher volume of resin $(10.0 \mathrm{~g})$ is presented in Fig 4b. The use of immobilized whey obtained from loading the whey at 100 and $200 \mathrm{ml}$ into SPFF, did not extend an antimicrobial activity, if compare to those on $1.0 \mathrm{~g}$ of immobilized whey. An extension of stable antimicrobial activity was achieved when the loaded whey was increased. We observed the reaction solution discharged from immobilized whey using $400 \mathrm{ml}$ at $40^{\text {th }}$ cycle, which resulted in an antimicrobial activity of $5 \log N_{0} / N_{\mathrm{t}}$ (data not presented). This experiment suggests that the extension of a stable antimicrobial activity of whey can be achieved by increasing the volume of both whey and resin.

\section{Recycled resin for immobilization of whey}

SP-FF is known as a reliable support for immobilization and easy to scale up the operations. Furthermore, it has been investigated that the Sepharose type of resin has high reusability (Dwevedi and Kayastha, 2009; Guo et al., 2004; Miroliaei et al., 2007; Tatsumi et al., 1996). Therefore, this challenged us to investigate 

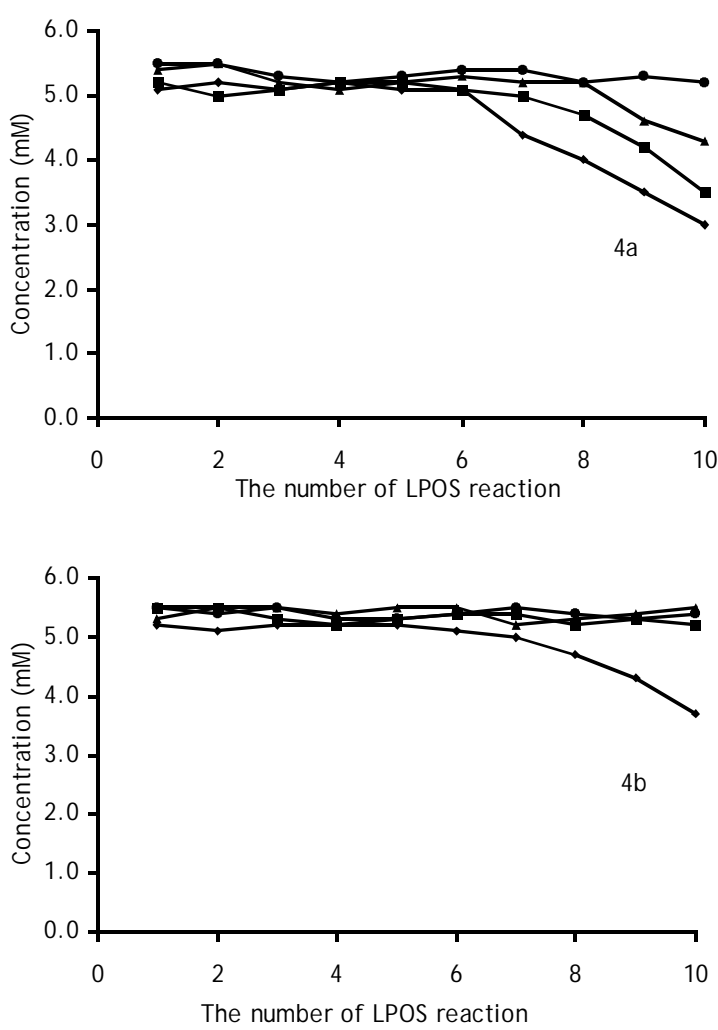

Figure 4. Antimicrobial activity of the scaled-up immobilized whey. The reaction solution discharged from immobilized whey was analyzed for antimicrobial activity against $S$. enteritidis at initial inocula of $6 \log \mathrm{CFU} / \mathrm{ml}$. (a) Antimicrobial activity of reaction solution discharged from $1.0 \mathrm{~g}$ of immobilized whey. Symbols represent the volume of whey solution added to SP-FF: $50(\boldsymbol{\nabla}), 100(\boldsymbol{\square})$, $150(\mathbf{\Delta})$, and $200 \mathrm{ml}(\bullet)$. (b) Antimicrobial activity of reaction solution discharged from $10.0 \mathrm{~g}$ of immobilized whey. Symbols represent the volume of whey solution loaded to SP-FF: $100(\diamond), 200(\boldsymbol{\square})$, $300(\mathbf{\Delta})$, and $400 \mathrm{ml}(\bullet)$. Data points are mean values of triplicate determination.

the reusability of SP-FF on immobilization of whey. According to manufacturer, the same SP-FF could be recycled several times after washing with $100 \mathrm{mM}$ PB (pH 7.0) containing $2 \mathrm{M} \mathrm{NaCl}$ to remove the attached enzyme. The next immobilization process was done after equilibrating the resin with $10 \mathrm{mM} \mathrm{PB}(\mathrm{pH} \mathrm{7.0)}$ ). Figure 5 shows the continuous production of $\mathrm{OSCN}^{-}$using immobilized whey on recycled SPFF. It can be seen that the recycling for three times was not affected to the yield of $\mathrm{OSCN}^{-}$, as seen in the similar production of $\mathrm{OSCN}^{-}$using recycled SP-FF. The recycled use of SP-FF did not affect the antimicrobial activity (data not presented). Ten times of reuse resulted in the no remarkable change on $\mathrm{OSCN}^{-}$production (data not presented). Based on this study, recycled SPFF has a great potential for producing antimicrobial agent without significant loss of antimicrobial activity; thus, the recycling of SP$\mathrm{FF}$, provides a cost-effective of $\mathrm{OSCN}^{-}$ production. In recent years, many authors use recycling ion exchange resin for immobilization (Du et al., 2004; Sprynskyy, 2005; Thornton et al., 2007). To the best of our knowledge, this is the first report presenting the use of recycled SP$\mathrm{FF}$, to produce antimicrobial agent $\mathrm{OSCN}^{-}$.

\section{CONCLUSION}

In this study, large scale of whey has been successfully immobilized on SP-FF. One gram of resin was able to maintain a high and stable IE in the range of whey up to $300 \mathrm{ml}$. Immobilized whey give an advantage toward storage time since it can maintain about $80 \%$ enzymatic activity within 4 weeks of storage. Immobilized whey was able to produce $\mathrm{OSCN}^{-}$and the increase in the whey amount used for immobilization, extended a stable of $\mathrm{OSCN}^{-}$production. The use of recycled SP-FF had no remarkable effect on the $\mathrm{OSCN}^{-}$ production and antimicrobial activity. Immobilization of whey onto SP-FF was able to scale-up and recycled which is a very attractive aspect for industrial application regarding the high cost of enzyme.

\section{REFERENCES}

Al-Baarri, A. N., M. Hayashi, M. Ogawa, S. Hayakawa. 2010a. Effect of mono- and disaccharides on the antimicrobial activity of bovine lactoperoxidase system. J. Food Prot. (In Press).

Al-Baarri, A. N., M. Ogawa, and S. Hayakawa. 2010b. Application of lactoperoxidase system using bovine whey and the effect of storage condition on lactoperoxidase activity. Int. J. Dairy Sci. (In Press).

Al-Baarri, A.N., V. Touch, M. Ogawa, and S. Hayakawa. 2010c. Application of an immobilized lactoperoxidase to continuous hypothiocyanite production. J. Food Sci. (Submitted).

Banks, J.G., and R.G. Board. 1985. Preservation by the Lactoperoxidase system (LP-S) of a contaminated infant milk formula. Lett. Appl. Microb. 1:81-85.

Borch, E., C. Wallentin, M. Rosén, and L. Björck. 
1989. Antibacterial effect of the lactoperoxidase/ thiocyanate/ hydrogen peroxide system against strains of Campylobacter isolated from poultry. J. Food Prot. 52:638-641.

Dwevedi, A., and A.M. Kayastha. 2009. Optimal immobilization of b-galactosidase from Pea (PsBGAL) onto Sephadex and chitosan beads using response surface methodology and its applications. Bioresour. Technol. 100:26672675.

Elliot, R.M., J.C. McLay, M.J. Kennedy, and R.S. Simmonds. 2004. Inhibition of foodborne bacteria by lactoperoxidase system in a beef cube system. Int. J. Food Microbiol. 91:7381.

Gurtler, J.B., and L.R. Beuchat. 2007. Inhibition of growth of Enterobacter sakazakii in reconstituted infant formula by the lactoperoxidase system. J. Food Prot. 70:2104-2110.

Kussendrager, K.D., and A.C.M.v. Hooijdonk. 2000. Lactoperoxidase: physico-chemical properties, occurence mechanism of action and application. Br. J. Nutr. 84:S19-S25.

Marks, N.E., A.S. Grandison, and M.J. Lewis. 2001. Challenge testing of the lactoperoxidase system in pasteurized milk. J. Appl. Microbiol. 91:735-741.

Min, S., L.J. Harris, and J.M. Krochta. 2005. Antimicrobial effect of lactoferrin, lysozyme, and the lactoperoxidase system and edible whey protein films incorporating the lactoperoxidase system against Salmonella enteritica dan Escherichia coli O157:H7. J. Food Sci. 70:M332-M338.

Nguyen, D.D.L., M.-N. Ducamp, M. Dornier, D. Montet, and G. Loiseau. 2005. Effect of the Lactoperoxidase System against Three Major Causal Agents of Disease in Mangoes. J. Food Prot. 68:1497-1500(4).

Orlando, U.S., A.U. Baes, W. Nishijima, and M. Okada. 2002. Preparation of agricultural residue anion exchangers and its nitrate maximum adsorption capacity. Chemosphere. 48:1041-1046.

Raybaudi-Massilia, R.M., J. Mosqueda-Melgar, R.
Soliva-Fortuny, and O. Martín-Belloso. 2009. Control of pathogenic and spoilage microorganisms in fresh-cut fruits and fruits juices by traditional and alternative natural antimicrobials CRFSFS. 8:157-180.

Reiter, B. 1985. The biological significance of the non-immunological protective proteins in milk: lysozyme, lactoferrin, lactoperoxidase, p. 281-336 Developments in Dairy Chemistry, Vol. 3. Elsevier Applied Science, London.

Saad, A.H. 2008. Activation of milk lactoperoxidase system for controlling pseudomonas in cow's milk. Int. J. Dairy Sci. 3:131-136.

Seifu, E., E.M. Buys, and E.F. Donkin. 2005. Significance of the lactoperoxidase system in the dairy industry and its potential applications: a review. Trends Food Sci. Technol. 16:137-154.

Seifu, E., E.M. Buys, E.F. Donkin, and I.-M. Petzer. 2004. Antibacterial activity of the lactoperoxidase system against food-borne pathogens in Saanen and South African Indigenous goat milk. Food Control. 15:447452.

Tatsumi, K., S. Wada, and H. lchikawa. 1996. Removal of chlorophenols from wastewater by immobilized horseradish peroxidase. Biotechnol. Bioeng. 51:126-130.

Touch, V., S. Hayakawa, S. Yamada, and S. Kaneko. 2004. Effect of lactoperoxidasethiocyanate-hydrogen peroxide system on Salmonella enteritidis in animal or vegetable foods. Int. J. Food Microbiol. 93:175-183.

Wisdom, R.A., P. Dunnill, M.D. Lilly, and R.A. Macrae. 1984. Enzyme esterification of fats: factors influencing the choice of support for immobilized lipase. Enzyme Microb. Technol. 6:443-446.

Wit, J.N.d., and A.C.M. van Hooydonk. 1996. Structure, functions, and application of lactoperoxidase in natural antimicrobial system. Neth. Milk Dairy J. 50: 227-244.

Wolfson, L.M., and S.S. Sumner. 1993. Antibacterial activity of the lactoperoxidase system: A Review. J. Food Prot. 56:887-892. 